\title{
Impact of Altitudinal Variation on the Phytochemical Profile, Anthelmintic and Antimicrobial Activity of Two Pinus Species
}

\author{
Wafaa M. Elkady ${ }^{1, * \mathbb{D}}$, Mariam H. Gonaid ${ }^{1}$, Miriam F. Yousif ${ }^{1}$, Mahmoud El-Sayed ${ }^{2}$ and Hind A. N. Omar $^{3}$ \\ 1 Department of Pharmacognosy, Faculty of Pharmacy, Future University in Egypt, Cairo 12311, Egypt; \\ mariam.hussein@fue.edu.eg (M.H.G.); miriam.fouad@fue.edu.eg (M.F.Y.) \\ 2 Microbiology Department, Faculty of Veterinary Medicine, Suez Canal University, Ismailia 41522, Egypt; \\ Mahmoud_elsayed@vet.suez.edu.eg \\ 3 Forestry and Range Sciences Department, Faculty of Natural Resources and Environmental Sciences, \\ Omar Al-Mukhtar University, Al Bayda' 00218-84, Libya; jehadalsaadi1982@gmail.com \\ * Correspondence: welkady@fue.edu.eg; Tel.: +20-111-353-3848
}

Citation: Elkady, W.M.; Gonaid, M.H.; Yousif, M.F.; El-Sayed, M.; Omar, H.A.N. Impact of Altitudinal Variation on the Phytochemical Profile, Anthelmintic and Antimicrobial Activity of Two Pinus Species. Molecules 2021, 26, 3170. https://doi.org/10.3390/ molecules 26113170

Academic Editor: Natalizia Miceli

Received: 5 May 2021

Accepted: 18 May 2021

Published: 26 May 2021

Publisher's Note: MDPI stays neutral with regard to jurisdictional claims in published maps and institutional affiliations.

Copyright: (C) 2021 by the authors. Licensee MDPI, Basel, Switzerland. This article is an open access article distributed under the terms and conditions of the Creative Commons Attribution (CC BY) license (https:/ / creativecommons.org/licenses/by/ $4.0 /)$.

\begin{abstract}
Active components from natural sources are the current focus in most pharmacological research to provide new therapeutic agents for clinical use. Essential oils from the Pinus species have been traditionally used in medicine. This study aimed to investigate the chemical profile of two Pinus species, Pinus halepensis L. and Pinus pinea Mill, from different altitudes in Libya and study the effect of environmental conditions on the biological activities of essential oils. A clevenger apparatus was used to prepare the essential oils by hydrodistillation. Analyses were done using GC/MS. Anthelmintic and antimicrobial activities were tested against the earthworm Allolobophora caliginosa, gram-positive bacteria, gram-negative bacteria, and fungi. Different chemical profiles were observed among all tested essential oils, and terpenes were the most dominant class. All studied essential oils from the Pinus species exhibited a remarkable anthelmintic activity compared to the standard piperazine citrate drug. Pinus halepensis from both altitudes showed broad-spectrum antimicrobial activity against all tested microorganisms, while Pinus pinea was effective against only Escherichia coli. From these findings, one can conclude that there are variations between studied species. The essential oil compositions are affected by environmental factors, which consequently affect the anthelmintic and antimicrobial activity.
\end{abstract}

Keywords: essential oils; environmental conditions; GC/MS; Pinus halepensis L.; Pinus pinea Mill

\section{Introduction}

Throughout history, medicinal plants have been used for the curing of many diseases. They have been considered valuable sources for the development of novel therapies [1]. Essential oil has been widely studied for different biological activities and uses in pharmaceutical industries. Essential oils from many Pinus species have been widely used in the drug, food, and cosmetic industries $[2,3]$.

Genus Pinus (Pinaceae) includes 70-100 species. They are evergreen trees grown as ornaments and timber trees as well as for their oleoresin, which upon distillation, yields turpentine or pine tar (colophony resin) and turpentine oil [4,5]. Pine products have acquired great commercial importance and have been long used in traditional medicine. Pine tars and turpentine oils are usually used externally as a rubefacient or counterirritant for rheumatic ailments, as an analgesic, and to treat skin diseases such as eczema, while pine needle oils have been used as inhalants for nasal decongestant, as expectorant, and to relieve cough [2,5].

Pinus halepensis and Pinus pinea are among the Pinus species that are cultivated in Libya; both are native to Mediterranean regions [5]. All parts of the P. halepensis (Aleppo pine) tree possess potential medicinal values [6]. The tree has several phytoconstituents as phenolic compounds, terpenes, and turpentine that have many valuable therapeutic 
applications $[7,8]$. P. pinea (stone pine or umbrella pine) were usually cultivated for their edible pine nuts. Their essential oil is usually used for many skin ailments and for herbal steam baths (inhalers) for respiratory problems. Resins were used as antiseptics and for kidney remedies $[9,10]$.

Reports have shown that the main volatile constituents usually found in P. halepensis are $\beta$-caryophyllene, $\alpha$-humulene, and aromadendrene. However, P. pinea is characterized by the presence of limonene $\beta$-phellandrene and $\alpha$-pinene [11].

Several studies have previously dealt with the constituents of P. halepensis and P. pinea needles, but the composition of the essential oil usually varies due to the geographic location, climatic conditions, and the time of collection; this may also affect its biological potential $[4,9,12,13]$. To the best of our knowledge, no comparative study has been published related to the chemical composition and anthelmintic and antimicrobial activities of P. halepensis and P. pinea essential oils in Libya, reflecting the impact of geographic difference and ecological conditions. Therefore, this work aims to study the impact of different altitudes on the phytochemical composition of the two species from different localities in Al-Jabal Al-Akhdar (Libya) and to study the effect of these phytochemical variations on the anthelmintic activity against the earthworm Allolobophora caliginosa and the antimicrobial activity against the yeast pathogen Candida albicans, as well as against gram-positive and gram-negative bacteria.

\section{Results}

\subsection{GC/MS Analysis of the Essential Oil}

Hydrodistillation of the aerial parts of P. halepensis and P. pinea from different localities vary in the yielded content. $P$. halepensis aerial parts showed a high percentage yield of Ph-1 (0.22\%) (P. halepensis at altitude $830 \mathrm{~m})$ and Ph-2 (0.59\%) (P. halepensis at altitude $75 \mathrm{~m})$, which was more than P. pinea, which yielded Pp-1 $(0.12 \%)$ (P. pinea at altitude $625 \mathrm{~m}$ ) and Pp-2 (0.22\%) (P. pinea at altitude $408 \mathrm{~m}$ ). The low altitude in both studied species (Ph-2 and $\mathrm{Pp}-2$ ) showed a relatively higher percentage yield (Table 1). These results were in agreement with a previous study in Algeria [4]. This could demonstrate that low altitudes have more preferable environmental conditions for essential oil production in Pinus. All isolated essential oils were faint yellow in color and their odors were characteristic.

Table 1. Chemical composition of the essential oils of P. halepensis (Ph-1 and Ph-2) and P. pinea (Pp-1 and Pp-2).

\begin{tabular}{|c|c|c|c|c|c|c|c|}
\hline & \multirow{3}{*}{ Chemical Name } & \multirow{2}{*}{\multicolumn{2}{|c|}{ Retention Index (RI) }} & \multicolumn{4}{|c|}{ Percentages $(\%)$} \\
\hline & & & & \multicolumn{2}{|c|}{ Pinus halepensis } & \multicolumn{2}{|c|}{ Pinus pinea } \\
\hline & & AI & RI & Ph-1 & Ph-2 & Pp-1 & Pp-2 \\
\hline & Monoterpene & & & & & & \\
\hline 1. & $\alpha$-Pinene & 932 & 939 & $8.54 \pm 0.50^{a}$ & $13.33 \pm 0.21^{b}$ & $13.82 \pm 0.03^{b}$ & $20.97 \pm 0.16^{c}$ \\
\hline 2. & Sabinene & 970 & 976 & $3.15 \pm 0.20$ & - & - & - \\
\hline 3. & $\beta$-pinene & 974 & 980 & $4.08 \pm 0.31$ & - & - & - \\
\hline 4. & $\beta$-Myrcene & 990 & 990 & $5.80 \pm 0.05^{a}$ & - & - & $1.37 \pm 0.06^{b}$ \\
\hline 5. & $\delta$-3-carene & 1008 & 1011 & $4.07 \pm 0.19$ & - & - & - \\
\hline 6. & p-Cymene & 1022 & 1022 & $1.39 \pm 1.10^{\mathrm{a}}$ & - & $0.82 \pm 0.21^{\mathrm{a}}$ & $0.69 \pm 0.11^{\mathrm{a}}$ \\
\hline 7. & Limonene & 1024 & 1029 & $1.49 \pm 0.02^{\mathrm{a}}$ & $6.77 \pm 0.02^{b}$ & $1.13 \pm 0.14^{\mathrm{a}}$ & $8.49 \pm 0.01^{b}$ \\
\hline 8. & $\gamma$-terpinene & 1054 & 1055 & $3.38 \pm 0.19^{\mathrm{a}}$ & - & $3.18 \pm 0.09^{a}$ & - \\
\hline \multirow[t]{3}{*}{9.} & $\alpha$-Terpinolene & 1018 & 1088 & $1.08 \pm 0.05^{\mathrm{a}}$ & - & $5.67 \pm 0.12^{b}$ & $4.75 \pm 0.21^{b}$ \\
\hline & & & & 27.18 & 20.1 & 24.62 & 36.27 \\
\hline & Oxygenated mor & rpenes & & & & & \\
\hline 10. & $\alpha$-Campholenal & 1130 & 1128 & - & - & $1.85 \pm 0.02^{\mathrm{a}}$ & $0.63 \pm 0.02^{\mathrm{a}}$ \\
\hline 11. & trans-pinocarveol & 1135 & 1136 & - & - & $4.89 \pm 0.25^{\mathrm{a}}$ & $1.08 \pm 0.12^{b}$ \\
\hline 12. & Pinocarvone & 1160 & 1164 & - & - & $1.77 \pm 0.31^{\mathrm{a}}$ & $1.35 \pm 0.05^{\mathrm{a}}$ \\
\hline
\end{tabular}


Table 1. Cont.

\begin{tabular}{|c|c|c|c|c|c|c|c|}
\hline & \multirow{3}{*}{ Chemical Name } & \multirow{2}{*}{\multicolumn{2}{|c|}{ Retention Index (RI) }} & \multicolumn{4}{|c|}{ Percentages (\%) } \\
\hline & & & & \multicolumn{2}{|c|}{ Pinus halepensis } & \multicolumn{2}{|c|}{ Pinus pinea } \\
\hline & & AI & RI & Ph-1 & Ph-2 & Pp-1 & Pp-2 \\
\hline 13. & Borneol & 1165 & 1168 & - & - & $2.47 \pm 0.42^{a}$ & $0.91 \pm 0.14^{\mathrm{a}}$ \\
\hline 14. & Myrtenol & 1194 & 1195 & - & - & $1.20 \pm 0.29$ & - \\
\hline 15. & Verbenone & 1204 & 1206 & - & - & $0.56 \pm 0.00$ & - \\
\hline 16. & trans-(+)-carveol & 1215 & 1219 & - & - & $1.04 \pm 0.17$ & - \\
\hline 17. & Carveol methyl ether & 1229 & 1229 & - & - & $1.09 \pm 0.07$ & - \\
\hline 18. & Carvone & 1239 & 1236 & - & - & $0.57 \pm 0.12$ & - \\
\hline 19. & Bornyl acetate & 1287 & 1285 & - & - & $1.49 \pm 0.06^{\mathrm{a}}$ & $1.29 \pm 0.07^{\mathrm{a}}$ \\
\hline 20. & Thymol & 1232 & 1232 & - & - & $5.53 \pm 0.05^{\mathrm{a}}$ & $0.65 \pm 0.01^{b}$ \\
\hline \multirow[t]{3}{*}{21.} & Carvacrol & 1298 & 1298 & - & - & $0.90 \pm 0.23^{\mathrm{a}}$ & $2.08 \pm 0.00^{\mathrm{a}}$ \\
\hline & & & & Zero & Zero & 23.36 & 7.99 \\
\hline & Sesquiterpen & hydroca & & & & & \\
\hline 22. & $\alpha$-Cubebene & 1345 & 1348 & - & - & $1.42 \pm 0.09^{\mathrm{a}}$ & $2.64 \pm 0.02^{a}$ \\
\hline 23. & $\alpha$-longipinene & 1350 & 1350 & $3.47 \pm 0.19^{\mathrm{a}}$ & - & $2.80 \pm 0.01^{\mathrm{a}}$ & $2.64 \pm 0.19^{a}$ \\
\hline 24. & $\beta$-Elemene & 1389 & 1390 & - & $2.06 \pm 0.07^{\mathrm{a}}$ & $1.26 \pm 0.05^{\mathrm{a}}$ & - \\
\hline 25. & $\beta$-Caryophyllene & 1417 & 1417 & $5.29 \pm 0.00^{\mathrm{a}}$ & $6.20 \pm 0.19^{\mathrm{a}}$ & $1.65 \pm 0.12^{b}$ & $5.39 \pm 0.01^{\mathrm{a}}$ \\
\hline 26. & Aromadenderene & 1439 & 1430 & $1.61 \pm 0.12^{\mathrm{a}}$ & $1.38 \pm 0.12^{\mathrm{a}}$ & $1.01 \pm 0.42^{\mathrm{a}}$ & - \\
\hline 27. & $\alpha$-Humulene & 1452 & 1454 & $3.12 \pm 0.05^{\mathrm{a}}$ & $2.0 \pm 0.29^{a}$ & $1.19 \pm 0.41^{b}$ & $3.39 \pm 0.20^{\mathrm{a}}$ \\
\hline 28. & Germacrene D & 1484 & 1485 & - & $0.68 \pm 0.02^{\mathrm{a}}$ & - & $7.81 \pm 0.03^{b}$ \\
\hline 29. & $\delta$-amorphene & 1511 & 1507 & - & - & $1.82 \pm 0.57^{\mathrm{a}}$ & $4.54 \pm 0.11^{b}$ \\
\hline 30. & Cis- $\alpha$-bisabolene & 1508 & 1508 & - & - & $1.38 \pm 0.67^{\mathrm{a}}$ & $0.65 \pm 0.09^{a}$ \\
\hline 31. & $\gamma$-cadinene & 1514 & 1514 & - & - & $0.21 \pm 0.03$ & - \\
\hline \multirow[t]{2}{*}{32.} & $\delta$-cadinene & 1523 & 1522 & $\begin{array}{c}2.63 \pm 0.01^{\mathrm{a}} \\
16.12\end{array}$ & $\begin{array}{c}2.03 \pm 0.09^{\mathrm{a}} \\
14.35\end{array}$ & $\begin{array}{c}4.54 \pm 0.07^{\mathrm{b}} \\
19.95\end{array}$ & $\begin{array}{c}2.62 \pm 0.02^{\mathrm{a}} \\
33.16\end{array}$ \\
\hline & Oxygenated sesqu & rpenes & & & & & \\
\hline 33. & Caryophyllene oxide & 1582 & 1581 & $1.39 \pm 0.03^{\mathrm{a}}$ & $4.45 \pm 0.03^{b}$ & $1.70 \pm 0.54^{\mathrm{a}}$ & $3.55 \pm 0.07^{b}$ \\
\hline 34. & $\begin{array}{c}\text { Aromadendrene } \\
\text { oxide }\end{array}$ & 1595 & 1595 & $2.37 \pm 0.10^{\mathrm{a}}$ & $\mathbf{1 2 . 1 3} \pm 0.36^{\mathrm{b}}$ & $3.63 \pm 0.21^{\mathrm{a}}$ & $1.57 \pm 0.08^{a}$ \\
\hline 35. & Cubenol & 1618 & 1616 & - & - & $0.89 \pm 0.15^{\mathrm{a}}$ & $0.92 \pm 0.15^{\mathrm{a}}$ \\
\hline 36. & Muurolol & 1640 & 1642 & - & - & $2.59 \pm 0.00^{\mathrm{a}}$ & $2.95 \pm 0.09^{\mathrm{a}}$ \\
\hline \multirow[t]{3}{*}{37.} & Vulgarol B & 1688 & 1688 & - & - & $2.55 \pm 0.02^{\mathrm{a}}$ & $1.74 \pm 0.01^{\mathrm{a}}$ \\
\hline & & & & 3.76 & 16.58 & 11.36 & 10.73 \\
\hline & Diterpene hydroc & cons & & & & & \\
\hline \multirow[t]{3}{*}{38.} & Cembrene & 1937 & 1932 & $2.54 \pm 0.05^{\mathrm{a}}$ & $8.23 \pm 0.07^{b}$ & $2.10 \pm 0.02^{\mathrm{a}}$ & - \\
\hline & & & & 2.54 & 8.23 & 2.1 & - \\
\hline & $\begin{array}{l}\text { Oxygenated } \\
\text { diterpenes }\end{array}$ & & & & & & \\
\hline 39. & Manool oxide & 1987 & 1994 & $3.94 \pm 0.02^{\mathrm{a}}$ & $2.55 \pm 0.25^{b}$ & $5.06 \pm 0.00^{\mathrm{a}}$ & $2.25 \pm 0.15^{b}$ \\
\hline 40. & Thunbergol & 2047 & 2047 & $5.76 \pm 0.58^{a}$ & $18.85 \pm 0.17^{b}$ & $6.16 \pm 0.02^{\mathrm{a}}$ & - \\
\hline 41. & $\begin{array}{l}\text { 1,4-menthano- } \\
\text { azulene }\end{array}$ & 2110 & 2110 & - & - & $2.67 \pm 0.09^{a}$ & $3.48 \pm 0.07^{a}$ \\
\hline 42. & Dehydro abietinal & 2279 & 2279 & $4.14 \pm 0.10$ & - & - & - \\
\hline 43. & Kaur-16-en-19-ol & 2346 & 2346 & $3.28 \pm 0.21$ & - & - & - \\
\hline 44. & $\begin{array}{c}\text { Methyl } \\
\text { dehydroabietate }\end{array}$ & 2359 & 2354 & $7.78 \pm 0.03^{\mathrm{a}}$ & - & $0.71 \pm 0.19^{b}$ & - \\
\hline 45. & Dehydro abietic acid & 2380 & 2380 & $5.74 \pm 0.31^{\mathrm{a}}$ & $1.38 \pm 0.27^{b}$ & $0.71 \pm 0.30^{b}$ & - \\
\hline \multirow[t]{2}{*}{46.} & $\begin{array}{c}\text { Abietic acid methyl } \\
\text { ester }\end{array}$ & 2377 & 2380 & $3.35 \pm 0.06^{\mathrm{a}}$ & - & $0.84 \pm 0.09^{b}$ & - \\
\hline & & & & 33.99 & 22.78 & 12.64 & 2.25 \\
\hline
\end{tabular}


Table 1. Cont

\begin{tabular}{|c|c|c|c|c|c|c|c|}
\hline & \multirow{3}{*}{ Chemical Name } & \multirow{2}{*}{\multicolumn{2}{|c|}{ Retention Index (RI) }} & \multicolumn{4}{|c|}{ Percentages (\%) } \\
\hline & & & & \multicolumn{2}{|c|}{ Pinus halepensis } & \multicolumn{2}{|c|}{ Pinus pinea } \\
\hline & & AI & RI & Ph-1 & Ph-2 & Pp-1 & Pp-2 \\
\hline \multicolumn{8}{|c|}{ Miscellaneous compounds } \\
\hline 47. & 2-pentadecanone & 1694 & 1698 & - & - & $1.59 \pm 0.01^{\mathrm{a}}$ & $0.70 \pm 0.21^{\mathrm{a}}$ \\
\hline \multirow[t]{4}{*}{48.} & Pentadecanal & 1716 & 1716 & - & - & $1.91 \pm 0.09$ & - \\
\hline & & & & - & - & 4.34 & 0.7 \\
\hline & Total & & & $89.39 \pm 4.10$ & $82.04 \pm 2.16$ & $94.03 \pm 6.75$ & $91.1 \pm 2.46$ \\
\hline & Yield\% & & & 0.22 & 0.59 & 0.12 & 0.22 \\
\hline
\end{tabular}

(Ph-1): P. halepensis at altitude $830 \mathrm{~m}$; (Ph-2): P. halepensis at altitude $75 \mathrm{~m}$; (Pp-1): P. pinea at altitude $625 \mathrm{~m}$; (Pp-2): P. pinea at altitude $408 \mathrm{~m}$. AI, Kovats index determined experimentally on HP-5MS column relative to C8-C28 n-alkanes. RI, Published Kovats retention indices. The main compounds are in bold. The values shown in this table were the average of three replicates and given as mean \pm SD $(n=3)$. One-way ANOVA followed by Duncan's multiple range test were used. Values with different superscripts (a-c) were significantly different at $p<0.05$. Values followed by a common letter in columns were not significant $(p>0.05)$.

Results are presented in Table 1, the most prominent components of which are shown in bold. The chemical structures of the major constituents of each essential oil are displayed in Figure 1.

\subsection{In Vitro Anthelmintic Activity of the Essential Oils}

The prepared essential oils from both Pinus species displayed a dose-dependent inhibition of motility (paralysis) for adult earthworms; the time required to produce such paralysis was calculated in minutes. The essential oils from P. halepensis Ph-1 and Ph-2 showed the most potent inhibitory effect compared to that obtained from P. pinea Pp-1 and Pp-2, as shown in Figure 2. Remarkably, the influence of higher concentrations (0.3\%) of $\mathrm{Ph}-1$ and $\mathrm{Ph}-2$ on worm paralysis was greater than that produced by the positive control, which was treated with piperazine citrate. Statistical analysis revealed no significant differences between the results obtained from the same species. On the other hand, there was a significant difference between the results obtained from the different species under investigation. Results showed that all essential oils from both Pinus species could eradicate worms in a short time compared to the reference drug piperazine citrate.

\subsection{In Vitro Antimicrobial Activity of the Essential Oils}

Results revealed that the essential oils obtained from P. halepensis possessed stronger and more significant antimicrobial effects against the tested gram-positive, gram-negative, and fungi when compared to that of $P$. pinea.

Essential oils of $P$. halepensis from both localities (Ph-1 and Ph-2) displayed effective antimicrobial activity against the tested gram-positive bacteria (Bacillus subtilis and Micrococcus lutea). However, moderate activity was observed against the tested gram-negative bacteria (Proteus mirabilis and E. coli). It also showed moderate antifungal activity against C. albican fungi. The essential oils from the low altitude locality (Ph-2) demonstrated greater activity than Ph-1 (Table 2). 


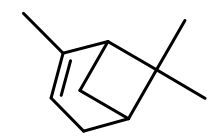

$\alpha$-Pinene

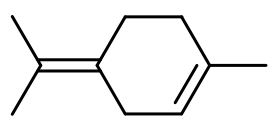

$\alpha$-Terpinolene<smiles>CC(C)CCCC(CCC(C)C)C(C)C</smiles>

Germacrene D

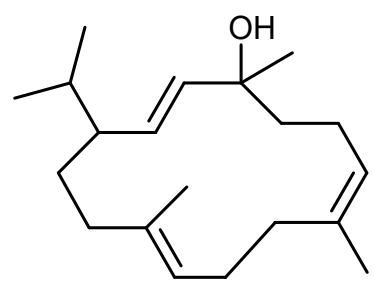

Thunbergol<smiles>C=CC(=C)CCC=C(C)C</smiles>

$\beta$-Myrcene

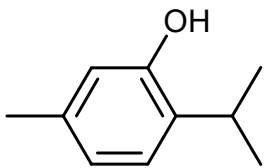

Thymol

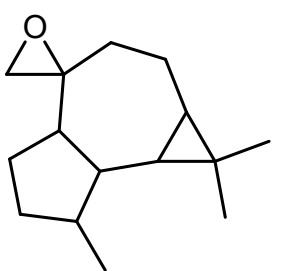

Aromadendrene oxide

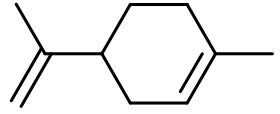

Limonene

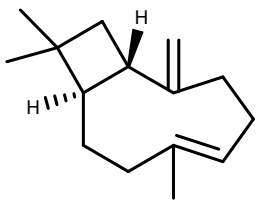

$\beta$-Caryophyllene

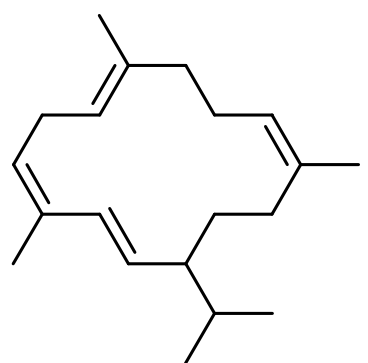

Cembrene

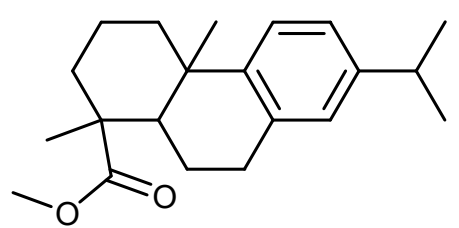

Methyl dehydroabietate

Figure 1. Structures of the major/marker constituents of P. halepensis (Ph-1 and Ph-2) and P. pinea (Pp-1 and Pp-2) essential oils.

\section{Anthelmintic activity of essential oils}

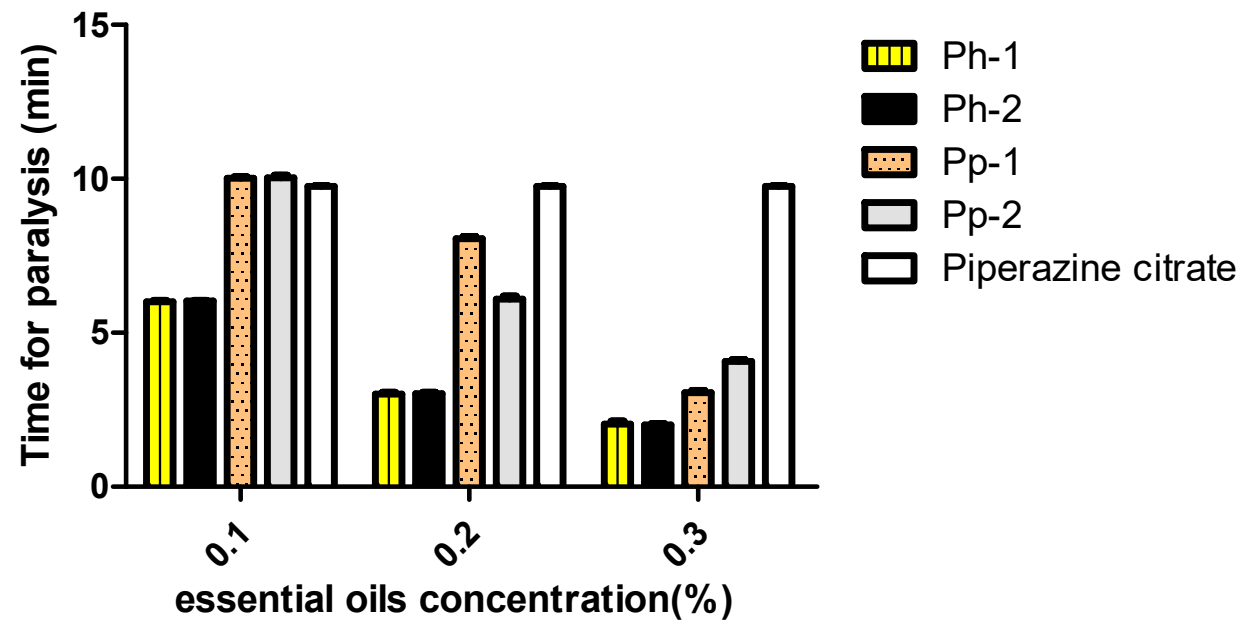

Figure 2. Anthelmintic activity of $P$. halepensis (Ph-1 and $\mathrm{Ph}-2)$ and P. pinea (Pp-1 and Pp-2) essential oils. Values are expressed as the means \pm SD of the inhibition zone of three independent experiments. 
Table 2. Antimicrobial activity of the essential oils of P. halepensis (Ph-1 and Ph-2) and P. pinea (Pp-1 and Pp-2).

\begin{tabular}{|c|c|c|c|c|c|c|}
\hline \multirow{3}{*}{$\begin{array}{c}\text { Micro- } \\
\text { Organisms }\end{array}$} & \multicolumn{5}{|c|}{ Diameter of Inhibition in $\mathrm{mm}$} & \multirow{3}{*}{ Nystatin } \\
\hline & \multicolumn{2}{|c|}{ P. halepensis } & \multicolumn{2}{|c|}{ P. pinea } & \multirow{2}{*}{ Cefotaxime } & \\
\hline & Pp-2 & Pp-1 & Ph-2 & Ph-1 & & \\
\hline \multicolumn{7}{|c|}{ Gram-Positive } \\
\hline Bacillus subtilis & $8 \pm 0.32$ & $18 \pm 0.91$ & - & - & $10 \pm 0.89$ & \\
\hline Micrococcus lutea & $39 \pm 0.54$ & $39 \pm 0.83$ & - & - & $27 \pm 0.93$ & \\
\hline \multicolumn{7}{|c|}{ Gram-Negative } \\
\hline Escherichia coli & $10 \pm 0.51$ & $18 \pm 0.90$ & $18 \pm 0.84$ & $8 \pm 0.36$ & $27 \pm 0.13$ & \\
\hline Proteus mirabilis & $14 \pm 0.56$ & $15 \pm 0.71$ & - & - & $25 \pm 0.83$ & \\
\hline \multicolumn{7}{|c|}{ Fungi } \\
\hline Candida albican & $10 \pm 0.25$ & $15 \pm 0.13$ & - & - & & $18 \pm 0.34$ \\
\hline
\end{tabular}

Values are expressed as the means \pm SD of the inhibition zone of three independent experiments.

A sensitivity test showed that cefotaxime, amikacin, and ceftriaxone had a significant effect against the different tested microorganism strains. As cefotaxime was found to have the greatest inhibition, it was considered as a reference drug for the evaluation of the antibacterial activity. The reference drug for the antifungal activity was nystatin (Table 3).

Table 3. Sensitivity of the tested microorganisms to different antibiotics.

\begin{tabular}{|c|c|c|c|c|c|}
\hline & \multicolumn{2}{|c|}{ Gram Negative } & \multicolumn{2}{|c|}{ Gram Positive } & \multirow{2}{*}{$\begin{array}{c}\text { Fungi } \\
\text { Candida albicans }\end{array}$} \\
\hline & Bacillus subtilis & $\begin{array}{c}\text { Micrococcus } \\
\text { Lutea }\end{array}$ & E. coli & Proteus mirabilis & \\
\hline Cefotaxime & 10 & 27 & 27 & 25 & - \\
\hline Erythromycin & 26 & 14 & - & - & - \\
\hline Polymyxin-B & 11 & 18 & 12 & - & - \\
\hline Cephalexin & 10 & 21 & - & - & - \\
\hline Amoxicillin & - & - & - & 15 & - \\
\hline Tetracycline & 27 & 29 & 21 & - & - \\
\hline Streptomycin & 20 & 27 & - & 15 & - \\
\hline Nalidixic Acid & 20 & 17 & - & 20 & - \\
\hline Fusidic Acid & 23 & 20 & - & - & - \\
\hline Amoxyclav & 11 & 14 & - & 25 & - \\
\hline Carbenicillin & 9 & 11 & - & 28 & - \\
\hline Gentamicin & 22 & 28 & 19 & 20 & - \\
\hline Chloramphenicol & 15 & 23 & 23 & - & - \\
\hline Amikacin & 27 & 21 & 19 & 21 & - \\
\hline Ceftriaxone & 12 & 20 & 27 & 20 & - \\
\hline Nystatin & & & & & 18 \\
\hline
\end{tabular}

Values are expressed as the means of inhibition zones of three independent experiments.

On the other hand, P. pinea essential oils (Pp-1 and Pp-2) showed moderate activity against $E$. coli only, with no obvious effect against either the tested gram-positive bacteria or fungi. The variation in chemical constituents of the essential oil could be responsible for the different antimicrobial effects. 


\section{Discussion}

Pinus is one of the conifers genera. It is considered one of the main sources of essential oils all over the world [4]. Essential oils have several medicinal properties that could be useful in the pharmaceutical field. Environmental factors have a great impact on the essential oil yield, composition, and, consequently, its biological activity $[4,13]$. This can be recognized from different earlier reports [6,14-19].

In the present study, the aerial parts of $P$. halepensis and P. pinea from different altitudes were collected. The prepared essential oils were analyzed. Comparing the results in this study with previous reports from different countries, we discovered that there were qualitative and quantitative differences in phytochemical composition. These variations have an impact on the tested biological activity. The results demonstrate that low altitude has an impact on the yield of the essential oil (Ph-2 and Pp-2).

GC and GC/MS analyses led to the identification of 48 constituents (Table 1). Monoterpene and sesquiterpene hydrocarbons are noted as the major classes of compounds in all four studied essential oils, especially in P. pinea ( $\mathrm{Pp}-2)$ (36.27 and 33.16\%, respectively). On the other hand, P. pinea from the high altitude $(\mathrm{Pp}-1)$ is found to be rich in oxygenated monoterpenes (23.36\%). Essential oils from both localities for P. halepensis (Ph-1 and Ph-2) are rich in oxygenated diterpenes (33.99 and 22.78\%, respectively).

The essential oil from $P$. halepensis resulted in the identification of 24 constituents in Ph-1, accounting for $89.39 \%$ of the total volatile oil composition. The main identified volatile compounds were $\alpha$-pinene $(8.54 \%)$, methyl dehydroabietate $(7.78 \%)$, and $\beta$-myrcene (5.80\%). In Ph-2, 14 compounds were identified, accounting for $82.04 \%$ of the total volatile oil composition. Thunbergol $(18.85 \%), \alpha$-pinene $(13.33 \%)$, and aromadendrene oxide $(10.84 \%)$ were the most prominent constituents. On the other hand, 42 compounds were identified in P. pinea ( $\mathrm{Pp}-1)$, accounting for $94.03 \%$ of the total volatile oil composition, characterized by the presence of $\alpha$-pinene (13.82\%), thunbergol (6.16\%), and $\alpha$-terpinolene (5.67\%). Finally, 28 constituents were identified in Pp-2, accounting for $91.10 \%$ of the total volatile oil composition and showing $\alpha$-pinene $(20.97 \%)$, limonene $(8.49 \%)$, germacrene $D$ $(7.81 \%)$ as the main constituents.

Anthelmintic remedies of plant origin will aid in the improvement of phytotherapeutic products, which are cost effective, nontoxic, and more accessible. In this study, all tested essential oils showed considerable anthelmintic activity against the earthworm Allolobophora caliginosa. The greatest activity was observed in the essential oil prepared from $P$. halepensis at a high altitude (Ph-1). This could be due to the presence of lipophilic compounds (monoterpene and sesquiterpene hydrocarbons), which have a great affinity to cell membranes, their inclusions prompting changes in the physicochemical properties of the membrane. Furthermore, oxygen-containing terpenes were found to be more effective than hydrocarbon terpenes [20]. Thunbergol (18.85\%) and aromadendrene oxide $(12.13 \%)$ are the major oxygen-containing terpenes in P. halepensis. The anthelmintic activity could be due to their presence as well as the synergistic activity of all other constituents.

A serious health problem is bacterial resistance to multiple antibiotics. Many reports have stated that essential oils are potential sources to produce novel antimicrobial compounds. In several reports, testing the individual essential oil component does not reproduce the same antimicrobial result as the whole one. For that reason, it is doubtful to attribute the biological activity of essential oil to a particular constituent. Bioactivity could be due to the synergistic effects of all components [21].

The antimicrobial activity was more recognizable in P. halepensis than in P. pinea. Results showed that gram-positive bacteria (Bacillus subtilis and Micrococcus lutea) are more sensitive to the tested essential oils than gram-negative bacteria (Proteus mirabilis and E. coli). Most essential oils showed the same effect [19]. This could be related to the nature of the gram-positive bacteria's outer membrane, which is composed of hydrophobic substances. On the other hand, the gram-negative bacteria's outer membrane is composed of hydrophilic constituents [19]. Terpenes and oxygenated terpenes which are more prominent in the $P$. halepensis essential oil (Table 1) can penetrate the hydrophobic outer membrane of 
gram-positive bacteria $[19,22]$. The antimicrobial activity is usually due to the synergetic effect of all constituents; however, $\alpha$-pinene is one of the major terpenes that present in all tested essential oils, and thus could have a great role in this activity [19].

\section{Materials and Methods}

\subsection{Plant Material}

Aerial parts (fresh needles) of P. halepensis and P. pinea were collected during April 2018 from different localities with different altitudes above sea level. The geographical coordinates of sampling sites are presented in Table 4.

Table 4. The geographical coordinates of sampling sites of P. halepensis (Ph-1 and Ph-2) and P. pinea $(\mathrm{Pp}-1$ and $\mathrm{Pp}-2)$.

\begin{tabular}{ccccc}
\hline & Localities & Altitude $(\mathrm{m})$ & \multicolumn{2}{c}{ Geographical Coordinates } \\
\hline P. halepensis $(P h-1)$ & Sidi Alhamry & $830 \mathrm{~m}$ & $32^{\circ} 38^{\prime} 286^{\prime \prime} \mathrm{N}$ & $21^{\circ} 48^{\prime} 164^{\prime \prime} \mathrm{E}$ \\
P. halepensis $(P h-2)$ & Alaslab & $75 \mathrm{~m}$ & $32^{\circ} 54^{\prime} 458^{\prime \prime} \mathrm{N}$ & $22^{\circ} 09^{\prime} 587^{\prime \prime} \mathrm{E}$ \\
P. pinea $(P p-1)$ & Werdama & $625 \mathrm{~m}$ & $32^{\circ} 47^{\prime} 334^{\prime \prime} \mathrm{N}$ & $21^{\circ} 46^{\prime} 313^{\prime \prime} \mathrm{E}$ \\
P. pinea $(P p-2)$ & Al-Mansura & $408 \mathrm{~m}$ & $32^{\circ} 50^{\prime} 10^{\prime \prime} \mathrm{N}$ & $21^{\circ} 51^{\prime} 10^{\prime \prime} \mathrm{E}$ \\
\hline
\end{tabular}

The plants' identity and authentication were done by Mr. Mossa Al-Seayti (Plant Taxonomy Department, Faculty of Science, Omar Al Mokhtar University, Al Bayda, Libya). Voucher samples (Ph-1, Ph-2, Pp-1, and Pp-2) were kept at the Faculty of Pharmacy, Omar Al-Mukhtar University. All plant samples were shade dried, powdered, and stored at a low temperature in closed containers until use.

\subsection{Essential Oils Isolation}

Aerial parts of $P$. halepensis and $P$. pinea from each altitude were separately hydrodistillated using a Clevenger apparatus for $6 \mathrm{~h}$ (100 g plant in $0.5 \mathrm{~L}$ distilled water). These preparations were carried out in triplicate for each plant. The percentage yield was estimated as the volume $(\mathrm{ml})$ of essential oil for each $100 \mathrm{~g}$ of the studied plant. Oils were dehydrated over anhydrous $\mathrm{Na}_{2} \mathrm{SO}_{4}$ and retained in dark glass sealed vials until further analyses.

\subsection{GC/MS Analyses}

GC analysis was done for each essential oil using an Agilent 6890 (Agilent Technologies, Palo Alto, CA, USA). It was equipped with an HP-5MS column ( $30 \mathrm{~m}, 0.320 \mathrm{ID}, 0.25$ $\mu \mathrm{m}$ film thickness). Helium carrier gas was used with a flow rate of $1 \mathrm{~mL} / \mathrm{min}$. The programmed temperature was applied, starting with $40^{\circ} \mathrm{C}$ for $3 \mathrm{~min}$ and then gradually increased by $8{ }^{\circ} \mathrm{C} / \mathrm{min}$ until $250^{\circ} \mathrm{C}$. A total of $1 \mu \mathrm{L}$ of each essential oil was injected individually at a split ratio of $1 / 15$. The temperatures of the injector and detector were kept at $250{ }^{\circ} \mathrm{C}$ and $280^{\circ} \mathrm{C}$, respectively. The relative amounts of the essential oil components were expressed as percentages attained by peak area normalization. An agilent mass selective detector was used for GC/MS analysis in all studied essential oils. The MS functioning parameters were: interface temperature: $280^{\circ} \mathrm{C}$; ion source temperature: $200{ }^{\circ} \mathrm{C}$; EI mode: $70 \mathrm{eV}$; scan range: $35-500 \mathrm{amu}$.

\subsection{Identification of Essential Oil Components}

Identification depended on the retention indices (RI), the comparison of their mass spectra with NIST-11 and Wiley library databases (accessed on 18 May 2021), and the published data in the literature [23]. A homologous series of $n$-alkanes (C8-C28) were injected under the same conditions to measure the relative retention indices. 


\subsection{In Vitro Anthelmintic Activity of the Essential Oils}

Some intestinal roundworms that can infect the human body are physiologically similar to the earthworm Allolobophora caliginosa, which was chosen as a model for the anthelmintic activity [24].

The anthelmintic activity study was done using three different doses of each essential oil $(1 \mathrm{ml}$ of $0.1 \%, 0.2 \%$, and $0.3 \% v / v$ in $1 \%$ aqueous tween 80$)$ against the earthworm Allolobophora caliginosa [1,21]. Briefly, an Anthelmintic test was applied on 24 worms. They were separated into 3 sets; each set had 6 worms (the length of each worm was greater than or equal to $10 \mathrm{~cm}$ ) and each set was treated with a certain dose of the prepared essential oils. The control group was prepared by $1 \%$ aqueous tween 80 . The standard anthelmintic drug, piperazine citrate (Sigma-Aldrich, St. Louis, MO, USA), was prepared as a $0.1 \%$ solution in tween 80. Piperazine citrate was used as a reference drug. The time required for complete inhibition of the worm response to external stimuli (death) was recorded. This was done by monitoring the absence of any type of worm movement after treatment with prepared essential oils. All essential oils and the reference drug solutions were freshly prepared.

\subsection{In Vitro Antimicrobial Activity of the Essential Oils}

Different prepared essential oils were tested for their antimicrobial activity. The paper disc diffusion method was applied [25]. Briefly, bacterial inoculums were prepared and spread on nutrients agar plates. Sterile filter papers (6 mm diameter) containing $5 \mu \mathrm{L}$ of each essential oil were placed using sterile forceps on the surface of the inoculated agar plate along with the positive control: ciprofloxacin $(5 \mu \mathrm{g})$ for the antibacterial activity, nystatin (100 units) for the antifungal activity, and the negative control (10\% DMSO in distilled water). All plates were incubated at $37^{\circ} \mathrm{C}$ for $24 \mathrm{~h}$. The zone of inhibition was calculated. The experiment was repeated three times for each bacterium culture and compared to the cefotaxime reference standard for the antibacterial activity and the nystatin for the antifungal activity (Wyeth, NJ, USA).

Standard reference strains were used to assess the antimicrobial activity (American Type Culture Collection "ATCC" for bacteria and fungi). The gram-positive bacteria used were Bacillus subtilis (ATCC 6051) and Micrococcus lutea (ATCC 4698), while the examined gram-negative bacteria were Escherichia coli (ATCC 8739) and Proteus mirabilis (ATCC 7002). The tested fungal microorganism was Candida albicans (ATCC 10231). The microbial inoculate and bacterial and fungal cultures were prepared as suspensions in Roux bottles. Trypticase soy agar (TSA) and Sabouraud dextrose agar (SDA) were used as media. This was done according to the guidelines of the manufacturer (Sigma, St. Louis, MO, USA).

A sensitivity test was carried out according to NCCLS (1997) [26] to assess the sensitivity of different strains of microorganisms to different types of antibiotics.

\section{Conclusions}

In conclusion, the current study highlighted the impact of different altitudes on essential oil chemical composition and the biological activity of two Pinus species from different localities in Libya. The low altitude (near the sea level) species showed relatively more preferable conditions for the production of more essential oil yield. All tested essential oils showed considerable anthelmintic activity. The antimicrobial activity in P. halepensis from the low altitude ( $\mathrm{Ph}-2)$ was the most recognized. Additional investigation is required to study the effects of other environmental factors and the subsequent effects on the biological activity of essential oils.

Author Contributions: W.M.E. designed the phytochemistry work, interpreted GC/MS data, and wrote the manuscript. M.H.G. and M.F.Y. supervised the work and revised the manuscript. H.A.N.O. prepared the essential oils and designed the phytochemistry work. M.E.-S. designed and performed the anthelmintic and antimicrobial assays and analyzed the data. All authors have read and agreed to the published version of the manuscript.

Funding: This research received no external funding. 
Institutional Review Board Statement: Not applicable.

Informed Consent Statement: Not applicable.

Data Availability Statement: The data presented in this study are available within the article.

Conflicts of Interest: The authors declare no conflict of interest.

Sample Availability: Samples of the essential oil are not available from the authors.

\section{References}

1. Dkhil, M.A.; Zreiq, R.; Hafiz, T.A.; Mubaraki, M.A.; Sulaiman, S.; Algahtani, F.; Abdel-Gaber, R.; Al-Shaebi, E.M.; Al-Quraishy, S. Anthelmintic and antimicrobial activity of Indigofera oblongifolia leaf extracts. Saudi J. Biol. Sci. 2020, 27, 594-598. [CrossRef] [PubMed]

2. Schiller, G. Therapeutic use of Aleppo pine (Pinus halepensis Mill.). In Medicinal and Aromatic Plants of the Middle-East; Springer: Dordrecht, The Netherlands, 2014; pp. 215-224.

3. Ulukanli, Z.; Karabörklü, S.; Bozok, F.; Burhan, A.; Erdogan, S.; Cenet, M.; Karaaslan, M.G. Chemical composition, antimicrobial, insecticidal, phytotoxic and antioxidant activities of Mediterranean Pinus brutia and Pinus pinea resin essential oils. Chin. J. Nat. Med. 2014, 12, 901-910. [CrossRef]

4. Fekih, N.; Allali, H.; Merghache, S.; Chaïb, F.; Merghache, D.; El Amine, M.; Djabou, N.; Muselli, A.; Tabti, B.; Costa, J. Chemical composition and antibacterial activity of Pinus halepensis Miller growing in West Northern of Algeria. Asian Pac. J. Trop. Dis. 2014, 4, 97-103. [CrossRef]

5. Evans, W.C. Trease and Evans Pharmacognosy, 15th ed.; Saunders, W.B., Ed.; Elsevier: Eidenburg, UK; London, UK; New York, NY, USA; Philadelphia, PA, USA; St. Louis, MO, USA; Sydney, Australia; Toronto, ON, Canada, 2002.

6. Ashmawy, N.A.; Al Farraj, D.A.; Salem, M.Z.; Elshikh, M.S.; Al-Kufaidy, R.; Alshammari, M.K.; Salem, A.Z. Potential impacts of Pinus halepensis Miller trees as a source of phytochemical compounds: Antibacterial activity of the cones essential oil and n-butanol extract. Agrofor. Syst. 2018, 94, 1403-1413. [CrossRef]

7. Mohareb, A.; Kherallah, I.; Badawy, M.; Salem, M.; Yousef, H. Chemical composition and activity of bark and leaf extracts of Pinus halepensis and Olea europaea grown in AL-Jabel AL-Akhdar region, Libya against some plant phytopathogens. J. Appl. Biotechnol. Bioeng. 2017, 3, 331-342.

8. Nam, A.M.; Tomi, F.; Gibernau, M.; Casanova, J.; Bighelli, A. Composition and chemical variability of the needle oil from Pinus halepensis growing in Corsica. Chem. Biodivers. 2016, 13, 380-386. [CrossRef] [PubMed]

9. Halloum, B.; Shakya, A.K.; Elagbar, Z.A.; Naik, R.R. GC-MS Analysis and Biological activity of Essential Oil of Fruits, Needles and Bark of Pinus pinea grown wildly in Jordan. Acta Pol. Pharm.-Drug Res. 2019, 76, 825-831. [CrossRef]

10. Amri, I.; Gargouri, S.; Hamrouni, L.; Hanana, M.; Fezzani, T.; Jamoussi, B. Chemical composition, phytotoxic and antifungal activities of Pinus pinea essential oil. J. Pest Sci. 2012, 85, 199-207. [CrossRef]

11. Gad, H.; Al-Sayed, E.; Ayoub, I. Phytochemical discrimination of Pinus species based on GC-MS and ATR-IR analyses and their impact on Helicobacter pylori. Phytochem. Anal. 2021. [CrossRef] [PubMed]

12. Hamrouni, L.; Hanana, M.; Amri, I.; Romane, A.E.; Gargouri, S.; Jamoussi, B. Allelopathic effects of essential oils of Pinus halepensis Miller: Chemical composition and study of their antifungal and herbicidal activities. Arch. Phytopathol. Plant Prot. 2015, 48, 145-158. [CrossRef]

13. Khouja, M.; Alves, R.C.; Melo, D.; Costa, A.S.; Nunes, M.A.; Khaldi, A.; Oliveira, M.B.P.; Messaoud, C. Morphological and chemical differentiation between Tunisian populations of Pinus halepensis Mill. Pinus brutia Ten. and Pinus pinaster Ait. Chem. Biodivers. 2021. [CrossRef] [PubMed]

14. Djerrad, Z.; Kadik, L.; Djouahri, A. Chemical variability and antioxidant activities among Pinus halepensis Mill. essential oils provenances, depending on geographic variation and environmental conditions. Ind. Crop. Prod. 2015, 74, 440-449. [CrossRef]

15. Mohareb, A.S.; Kherallah, I.; Badawy, M.E.; Salem, M.; Faraj, H. Chemical composition and antibacterial activity of essential oils isolated from leaves of different woody trees grown in Al-Jabel al-Akhdar region, Libya. Alex. Sci. Exch. J. 2016, 37, 358-371.

16. Djerrad, Z.; Djouahri, A.; Kadik, L. Variability of Pinus halepensis Mill. Essential oils and their antioxidant activities depending on the stage of growth during vegetative cycle. Chem. Biodivers. 2017, 14, e1600340. [CrossRef] [PubMed]

17. Rodrigues, A.M.; Mendes, M.D.; Lima, A.S.; Barbosa, P.M.; Ascensão, L.; Barroso, J.G.; Pedro, L.G.; Mota, M.M.; Figueiredo, A.C. Pinus halepensis, Pinus pinaster, Pinus pinea and Pinus sylvestris essential oils chemotypes and monoterpene hydrocarbon enantiomers, before and after inoculation with the pinewood nematode Bursaphelenchus xylophilus. Chem. Biodivers. 2017, 14, e1600153. [CrossRef] [PubMed]

18. Bouyahya, A.; Belmehdi, O.; Abrini, J.; Dakka, N.; Bakri, Y. Chemical composition of Mentha suaveolens and Pinus halepensis essential oils and their antibacterial and antioxidant activities. Asian Pac. J. Trop. Med. 2019, 12, 117. [CrossRef]

19. Haichour, R.; Ramdani, M.; Lograda, T.; Chalard, P.; Figueredo, G. Chemical composition and antimicrobial activity of Pinus halepensis from Algeria. Biodiversitas 2020, 21, 4345-4360.

20. Maggiore, M.A.; Albanese, A.A.; Gende, L.B.; Eguaras, M.J.; Denegri, G.M.; Elissondo, M.C. Anthelmintic effect of Mentha spp. essential oils on Echinococcus granulosus protoscoleces and metacestodes. Parasitol. Res. 2012, 110, 1103-1112. [CrossRef] [PubMed] 
21. Khalil, N.; El-Jalel, L.; Yousif, M.; Gonaid, M. Altitude impact on the chemical profile and biological activities of Satureja thymbra L. essential oil. BMC Complementary Med. Ther. 2020, 20, 186. [CrossRef]

22. Mitić, Z.S.; Jovanović, B.; Jovanović, S.Č.; Mihajilov-Krstev, T.; Stojanović-Radić, Z.Z.; Cvetković, V.J.; Mitrović, T.L.; Marin, P.D.; Zlatković, B.K.; Stojanović, G.S. Comparative study of the essential oils of four Pinus species: Chemical composition, antimicrobial and insect larvicidal ac-tivity. Ind. Crop. Prod. 2018, 111, 55-62. [CrossRef]

23. Adams, R.P. Identification of Essential Oils Components by Gas Chromatography/Mass Spectrometry, 4th ed.; Publ, A., Ed.; Allured Publishing Corporation: Carol Stream, IL, USA, 2007.

24. Dkhil, M.A.; Thagfan, F.A.; Abdel-moniem, S.H.; Al-Shaebi, E.M.; Abdel-Gaber, R.; Al-Quraishy, S. Anthelmintic, anticoccidial and antioxidant activity of Salvadora persica root extracts. Saudi J. Biol. Sci. 2019, 26, 1223-1226. [CrossRef] [PubMed]

25. Boutkhil, S.; El Idrissi, M.; Chakir, S.; Derraz, M.; Amechrouq, A.; Chbicheb, A.; El Badaoui, K. Antibacterial and antifungal activity of extracts and essential oils of Seriphidium herba-alba (Asso) Soják and their combination effects with the essential oils of Dysphania ambrosioides (L.) Mosyakin \& Clemants. Acta Bot. Gall. 2011, 158, 425-433.

26. Standard, A. NCCLS Document M27-A; NCCLS: Wayne, PA, USA, 1997. 